\title{
Legal Protection for Consumers in On Sale Purchase Agreement
}

\author{
Dharu Triasih ${ }^{1 *}$, B. Rini Heryanti ${ }^{1}$, and Endah Pujiastuti ${ }^{1}$ \\ ${ }^{1}$ Faculty of Law, Semarang University, Semarang, Indonesia
}

\begin{abstract}
One of the most significant developments at this time is the online buying and selling transactions. Sellers and buyers do not need faceto-face buying and selling transactions. They only need to have an internet connection that will take them in cyberspace. Until now, there is still a legal vacuum about it in Indonesia. The existence of E-Commerce makes it is necessary to learn about consumer protection in an online sale and purchase agreement. Therefore, there will be no legal dispute that can harm various parties commercially. The approach method used in this study was an empirical juridical approach. This research was conducted in Semarang, Pekalongan, and Magelang. The selection of three cities in Central Java is based on a purposive sampling method. Data were gained by means of an interview, questionnaire, and literature study. Primary data, secondary data. Qualitative analysis. The results showed that the main principle of online transactions in Central Java still prioritized the aspects of trust of sellers and buyers. The principles of online transaction security has not become a major concern for sellers and buyers, especially in small to medium scale transactions.
\end{abstract}

\section{Introduction}

\subsection{Background}

One of the most significant developments at this time is online buying and selling transactions or E-Commerce. Sellers and buyers do not need to be face to face to make buying and selling transactions, but only need to have an internet connection that will take them in cyberspace. Agreements for buying and selling that occur between parties are also conducted electronically, either by e-mail or by other means. Buying and selling transactions carried out through the internet may not stop, even every day the latest technology is always found in the world of the internet, while legal protection and certainty for internet users is insufficient, thus must be endeavored to achieve legal balance in the intended conditions.

Until now there is still a legal vacuum in Indonesia because it has not accommodated the legal requirements of an electronic contract specifically. The existence of E-Commerce is important to understand in relation to consumer protection in an online sale and purchase agreement so that it does not become a legal dispute that can harm various parties commercially.

\footnotetext{
* Corresponding author: dharutriasih.fhusm@yahoo.co.id
} 
Online shopping itself without realizing it can be very preferred for buyers who once feel well served or satisfied in the transaction, so than do other similar transactions again on the same site. Not infrequently among buyers have a sense of curiosity to access other online shopping sites. The trust or mutual trust is actually the main key to an online transaction. It is this belief that overrides the traditional pattern of dealing with each other face-to-face. One will not know that trust is damaged until one day the person is experiencing personal problems through an online transaction. No less tragic is when they learn about the problem of how law enforcement in Indonesia is against fraud cases or online shopping lawsuits that are not in favor of the buyer.

\subsection{Problem}

a. What is the legal protection for consumers in an online sale and purchase agreement according to the Consumer Protection A?

b. What is the legal protection for consumers in an online sale and purchase agreement according to the Information and Electronic Transaction Law/ITE?

\section{Method}

The approach method used in this study is an empirical juridical approach, which is a study that emphasizes legal science, but also tries to examine the rules of law in society. This research was conducted by collecting and studying primary, secondary legal materials. and tertiary. According to Soerjono Soekanto, it was argued that: "A legal research is basically a scientific activity based on certain methods, systematics and thoughts which aims to study one or several specific legal symptoms by analyzing them, except that there is also a thorough examination of these legal facts for then what is caused in the symptoms concerned ".

Primary legal materials include The Civil Code third book on Engagement, Law of the Republic of Indonesia Number 36 of 1999 concerning Telecommunications, Law of the Republic of Indonesia Number 8 of 1999 concerning Consumer Protection Law, Law of the Republic of Indonesia Number 11 of 2008 concerning Information and Electronic Transactions. Secondary data legal material is a legal material that provides instructions and explanations of primary legal materials, such as the work of legal experts and other documents relating to the problem under study. Tertiary legal materials, supporting legal materials that provide instructions and explanations of secondary legal materials and primary law, namely legal-dictionaries, magazines/journals or newspapers as far as information is relevant to the research material. The field research study was conducted to obtain primary data, with the technique of conducting in-depth interviews with informants and respondents that the researchers had determined.

\section{Results and Discussion}

\subsection{Legal Protection for Consumers In the Sale and Purchase Agreement Onliine According to the Consumer Protection Act}

Buy and sell online, known as E-commerce. E-commerce is a business process using electronic technology that connects companies, consumers, and society in the form of electronic transactions. Thus, in principle, business with e-commerce is a business activity. E-commerce in a narrow sense is defined as a sale and purchase of a product, service or information between business partners using a computer network based on the internet. 
Whereas e-commerce in the broad sense is defined as the term e-business, which includes not only online transactions but also includes customer service, trade relations with business partners, and internet transactions in an organization.[1]

In the Consumer Protection Law regulating consumer rights, Article 4 of Law Number 8 of 1999 concerning Consumer Protection states that consumer rights are: [2]

a. The right to comfort, security and safety in consuming goods and/or services;

b. The right to choose goods and/or services and obtain the goods and/or services in accordance with the exchange rate and the conditions and guarantees promised;

c. Right to correct, clear and honest information regarding the condition and guarantee of goods and/or services;

d. The right to hear opinions and complaints about the goods and/or services used;

e. The right to get proper advocacy, protection, and efforts to resolve consumer protection disputes;

f. The right to get consumer education and guidance;

g. The right to download is treated or served correctly and honestly and is not discriminatory;

h. The right to get compensation, compensation and/or replacement, if the goods and/or services received are not in accordance with the agreement or not as they should be;

i. Rights regulated in other laws and regulations.

Obligations for businesses (in this case online sellers), in accordance with Article 7 of Law Number 8 of 1999 concerning Consumer Protection are: [3]

a. Goodwill in conducting its business activities;

b. Provide correct, clear and honest information regarding the condition and guarantee of goods and/or services and provide an explanation of the use, repair, and maintenance;

c. Treat or serve consumers correctly and honestly and not discriminatory;

d. Ensure the quality of goods and/or services produced and/or traded based on the provisions of the quality standards of goods and/or services that apply;

e. Give consumers the opportunity to test, and/or try certain goods and/or services and provide guarantees and/or guarantees for goods made and/or traded;

f. Provide compensation, compensation and/or compensation for losses due to the use, use and use of goods and/or services traded;

g. Give compensation, compensation and/or reimbursement if the goods and/or services received or utilized are not in accordance with the agreement.

Article 8 of Law Number 8 of 1999 concerning Consumer Protection prohibits business actors from trading goods/services that are not in accordance with promises stated in the label, etiquette, information, advertisement or promotion of the sale of goods and/or services. Based on this article, the non-conformity of the goods specifications received with the goods listed in the advertisement/photo of the goods offer is a form of violation/prohibition for business actors in trading goods. Consumers in accordance with Article 4 letter h of Law Number 8 of 1999 concerning Consumer Protection are entitled to compensation, compensation and/or replacement if the goods and/or services received are not in accordance with the agreement or not as they should. Whereas, the business actor itself in accordance with Article 7 letter $g$ of Law Number 8 of 1999 concerning Consumer Protection is obliged to provide compensation, compensation and/or reimbursement if the goods and/or services received or utilized are not in accordance with the agreement. If a business actor does not carry out his obligations, business actors can be convicted under Article 62 of Law Number 8 of 1999 concerning Consumer Protection. 


\subsection{Legal Protection for Consumers in the Sale and Purchase Agreement according to the Law Number 11 of 2008 concerning Information and Electronic Transactions}

At present, the development of online trading is growing rapidly. In addition to having a positive impact on the development and economic growth of Indonesia, it will also cause problems which of course must be found how to solve it using laws and regulations in force in Indonesia.

For the people of Indonesia, this is related to very important legal issues. The importance of legal issues in the field of E-Commerce is primarily in providing protection for parties who conduct transactions via the internet. Special regulations that regulate transactions via the internet, namely Law Number 11 of 2008 concerning Information and Electronic Transactions which are hereinafter abbreviated to UUITE. In Article 1 paragraph 2 of the UUITE, it is stated that electronic transactions are legal actions carried out using computers, computer networks or other electronic media. Buying and selling transactions electronically are one manifestation of these provisions. Electronic contracts in electronic transactions must have the same legal force as conventional contracts.

Electronic transactions involving parties from within the country, namely the Indonesian state, it is not difficult to establish the applicable legal rules if problems occur. Automatically the applicable law is Indonesian law so that both Burgelijk Wetboek and the Consumer Protection Act can be applied to resolve disputes that arise.

In Article 38 of Law No. 11 of 2008 concerning Information and Electronic Transactions itself affirms that "Everyone can file a lawsuit against the party that carries out the Electronic System and/or uses Information Technology that causes losses". According to this article, the public can file a lawsuit in a representative manner against the party that carries out the Electronic System and/or uses Information Technology.

Furthermore, the legal provisions are contained in Article 46 UUITE are as follows:

(1) Every person who fulfills the elements referred to in Article 30 paragraph (1) shall be sentenced to a maximum imprisonment of 6 (six) years and/or a fine of no more than Rp. 600,000,000.00 (six hundred million rupiahs).

(2) Every person who fulfills the elements as referred to in Article 30 paragraph (2) shall be punished with a maximum sentence of 7 (seven) years and/or a fine of a maximum of Rp. 700,000,000.00 (seven hundred million rupiahs).

(3) Every person who fulfills the elements referred to in Article 30 paragraph (3) shall be sentenced to a maximum of 8 (eight) years of imprisonment and/or a maximum fine of Rp. 800,000,000.00 (eight hundred million rupiahs).

Article 49 paragraph (1) PP PSTE affirms that Business Actors offering products through the Electronic System must provide complete and correct information relating to contract conditions, producers and products offered. In the next paragraph, it is further emphasized that business actors are obliged to provide clarity of information about advertisement offerings.

Pursuant to Article 49 paragraph (3) PP PSTE specifically regulates the matter, namely Business Actors must provide a time limit for consumers to return the items sent if they are not in accordance with the agreement or there are hidden defects. received not in accordance with the photo on the online store advertisement (as a form an offer), the consumer can sue the Business Actor (in this case the seller) in a civil case under the pretext of the interpretation of the sale and purchase transaction that has been done with the seller.

The agreement to buy and sell online in principle is the same as buying and selling factually in general. Consumer protection laws related to online buying and selling transactions are not different from the laws that apply in a real sale and purchase transactions. The only difference is the use of internet facilities or other telecommunications facilities. The 
result is that it is difficult to execute online buying and selling transactions or actual actions in the event of a dispute or fraud. Cyber nature in electronic transactions allows everyone, both sellers, and buyers, to disguise or falsify identities in every transaction or sale and purchase agreement.

In the event that a business actor or seller turns out to use a false identity or commits tricks in buying and selling online, the business actor can also be convicted under Article 378 of the Criminal Code concerning fraud and Article 28 paragraph (1) of the ITE Law on spreading false and misleading news that results in loss consumers in buying and selling agreements online. which result in harming the public, in accordance with the provisions of the Law.

Article 39 of Law No. 11 of 2008 concerning Information and Electronic Transactions explains that "Civil lawsuits are carried out in accordance with the provisions of the Legislation. In addition to the civil claim settlement, the parties can also resolve disputes through arbitration, or alternative dispute resolution institutions others in accordance with the provisions of the Law. This is in accordance with the provisions in Article 23 of Law No. 8 of 1999 concerning Consumer Protection which states that "Business actors who refuse and/or do not respond and/or do not meet compensation for consumer demands can be sued through a consumer dispute resolution body or submitted to the judiciary at the consumer's seat." [\{ Ahmadi Miru According to Indonesian law, civil lawsuits can be based on two reasons, namely default and violation of the law (onrechtmatigedaad). The legal basis is based on the provisions of Book III Article 1243 BW for default and Article 1365 BW for illegal acts.

\section{Conclusion}

a. Legal Protection for consumers in an online sale and purchase agreement according to the Law on Consumer Protection contained in Article 8 of the UUPK, which prohibits business actors from trading goods / services that are not in accordance with promises stated in labels, etiquette, information, advertisements or sales promotions of goods and / or the service. Consumer rights in accordance with Article 4 letter $\mathrm{h}$ of the PK Law are entitled to compensation, compensation and/or reimbursement if the goods and/or services received are not in accordance with the agreement or not as they should be. Business actors in accordance with Article 7 letter $g$ of the PK Law are obliged to provide compensation, compensation and/or reimbursement if the goods and/or services received or utilized are not in accordance with the agreement. If a business actor does not carry out his obligations, business actors can be convicted under Article 62 of the UUPK.

b. Legal Protection for consumers in an online sale and purchase agreement according to the ITE Law Article 49 paragraph (1) PP PSTE affirms that Business Actors offering products through the Electronic System must provide complete and correct information relating to contract conditions, producers, and products offered.

\section{References}

1. M. Fuady, Pengantar Hukum Bisnis Menata Bisnis Modern di Era Global (PT Citra Aditya Bakti, Bandung, 2008).

2. A. Miru, S. Yodo, Consumer Protection Law (Raja Grafindo Persada, Jakarta, 2011)

3. Zulham, Hukum Perlindungan Konsumen (Kencana Prenada Media Group, Jakarta 2013). 